\title{
DETERMINATION OF THE VITAMIN-MINERAL PREPARATION 'ENERGOLIT’ STABILITY FOR THE TREATMENT OF METABOLIC DISORDERS IN ANIMALS
}

\author{
Sachuk R. M. \\ Research Epizootology Station of the Institute of Veterinary Medicine of the National \\ Academy of Agrarian Sciences of Ukraine, Rivne, Ukraine, e-mail: sachuk.08@ukr.net
}

\begin{abstract}
Summary. The aim of experiments was the study the shelf life of the injectable preparation 'Energolit' when stored in vials of light glass. Studies were carried out at a temperature within from +10 to $+25^{\circ} \mathrm{C}$ and relative humidity $(60 \pm 5 \%)$. Experiments were carried out in 3, 6, 9, 12, 18, 24 months, and one day after the expiration date after the puncture of the stopper with a sterile injection needle.

The control was the newly prepared preparation. We checked organoleptic parameters, $\mathrm{pH}$, microbial contamination to assess the quality of the 'Energolit'. In addition, we determined the quantitative content of vitamins $\mathrm{B}_{1}, \mathrm{~B}_{2}, \mathrm{~B}_{3}, \mathrm{~B}_{5}, \mathrm{~B}_{6}$, and $\mathrm{B}_{12}$ by methods described in the 'State Pharmacopoeia of Ukraine'.

Three tested batches of the preparation 'Energolit' showed constant composition throughout all period of study during two years of storage, as well as one day after the puncture of the stopper with a sterile injection needle in the primary packaging. Experimental samples of the preparation were within possible variation during the tests on changes of $\mathrm{pH}$, identity and content of the vitamins $\mathrm{B}_{1}, \mathrm{~B}_{2}, \mathrm{~B}_{3}, \mathrm{~B}_{5}, \mathrm{~B}_{6}$, and $\mathrm{B}_{12}$. Microbial contamination (Escherichia coli, Staphylococcus aureus, Pseudomonas aeruginosa) was not detected. Fungi contamination were not detected during the experiment. Fungi contamination was less than $10 \mathrm{CFU} / \mathrm{ml}$ one day after the puncture.

The optimal storage terms of the preparation has been determined. The findings indicated, that the shelf life of the preparation 'Energolit' is 2 years. The $\mathrm{pH}$ and mass fraction of the vitamins $\mathrm{B}$ group were unchanged or were within the limits of possible variation in the tested samples during the experiment. Microbial contamination was not detected.
\end{abstract}

Keywords: B vitamins, stability, shelf life, 'Energolit'

Introduction. Despite the significant amount of therapeutic agents for the treatment of metabolic disorders in the animal, the pharmaceutical market in Ukraine feels the need for modern, complex and affordable preparations. The present realities led to the lack of planning and systematic veterinary and zootechnical measures in the private sector. Farmers expects at veterinarian to solve all problems with one injection. Therefore, the promising direction of veterinary pharmacology is the combination of multicomponent preparations. They have a wider range of applications due to the synergy and compatibility of the combined components.

Therefore, at the request of the veterinary preparations market and with the purpose of import substitution, Private Enterprise 'Biopharm', together with the Rivne Research Station of Epizootology of the Institute of Veterinary Medicine of the NAAS, developed a new vitamin and mineral preparation 'Energolit'. The application of that preparation optimizes the cost, reduce the timing of medical procedures and simplify therapeutic manipulations.

The composition of the product includes vitamin B complex, glucose, sorbitol, sodium salts, potassium, calcium, magnesium and amino acids (arginine, glutamic acid, lysine, and methionine). 'Energolit' is recommended for the treatment of metabolic disorders of various etiologies, including ketosis and acidosis; hepatitis and toxicosis, in the period of recovery after prior diseases; for dehydration of the body from diarrhea, vomiting and blood loss.

The preparation is used for weakened and depleted animals to normalize metabolism during pregnancy and lactation, for increase resistance to physical activity and stress, and also to horses and dogs - before intensive work, competitions and long-term transportation (Sachuk, 2018).

A prerequisite for the registration of new preparations is the study of their stability in storage. The study of the expiration date of new preparations in order to obtain information on changes in their quality over time under the influence of environmental factors (temperature, humidity, illumination, etc.) is an obligatory type of scientific research (Kotsiumbas et al., 2006).

The aim of the work was to study the shelf life of the injectable preparation 'Energolit' when stored in vials of light glass.

Materials and methods. Investigation of the injection preparation 'Energolit' was conducted on three pilotindustrial series $(010216,010316,010416)$ made on LLC 'DEVIE' (Ukraine). The tests were carried out on as packaged preparation (a vial of light glass II-250-B-2 according TUU (Technical Specifications of Ukraine) 26.1-04763746-025:2008; a cap of aluminum with perforation type K-3-28; rubber cork for block, type 28-B3). To determine the shelf life of the preparation stability, studies were conducted at recommended storage conditions: at a temperature from +10 to $+25^{\circ} \mathrm{C}$ and 
relative humidity ( $60 \pm 5 \%$ ), in periods: $3,6,9,12,18$, and 24 months. And one day after the end after the piercing of the stopper with a sterile injection needle. The test sample was a newly prepared preparation.

According to normative requirements and literary sources, during the test, the fundamental properties of the preparation were determined: identification of active substances, control of the basic physical indicators and the most accurate analytical techniques for their determination were selected. In the case of 'Energolit', the organoleptic parameters (appearance, color, precipitate, etc.), $\mathrm{pH}$, presence of microbial contamination were determined, and the quantitative content of vitamins $B_{1}$, $\mathrm{B}_{2}, \mathrm{~B}_{3}, \mathrm{~B}_{5}, \mathrm{~B}_{6}$, and $\mathrm{B}_{12}$ was identified and determined (Kotsiumbas et al., 2006; USPCQM, 2014-2018; Tykhonov and Yarnykh, 2016).

The study of microbiological purity was carried out by direct inoculation method according to the 'State Pharmacopoeia of Ukraine' (SPU) procedure (USPCQM, 2014-2018).

Microbiological limit tests of the injection solution included the quantification of viable bacteria and fungi, as well as the identification of certain types of microorganisms not available in sterile medicinal products. Inoculation of medium for the next dilution of the preparation: medium No. $1-1: 10$, medium No. $2-$ 1:10, medium No. $3-1: 10$, medium No. $4-1: 20$. For this, $1.0 \mathrm{ml}$ of the preparation was shaken with $10 \mathrm{ml}$ of phosphate buffer ( $\mathrm{pH} 7.0) .1 \mathrm{ml}$ of the resulting solution of the preparation was inoculated on a liquid and solid Sabouraud's medium, meat infusion broth containing $2 \%$ glucose, a thioglycollate medium and a blood agar. All inoculated medium was incubated at a temperature of 30 $35^{\circ} \mathrm{C}$. Daily, as well as after the end of the incubation period, inoculations were examined in diffused light. As a control, nutrient media were used without adding the preparation. In addition, studies have been conducted on the presence of bacteria Escherichia coli, Staphylococcus aureus, Pseudomonas aeruginosa (USPCQM, 2014-2018).

The determination of the identity of vitamins $B_{1}, B_{2}$, $\mathrm{B}_{3}, \mathrm{~B}_{5}, \mathrm{~B}_{6}$, and $\mathrm{B}_{12}$ was carried out by liquid chromatography method, comparing the peak time of $\mathrm{B}$ vitamins in chromatograms of Work Solution Reference Standards (WSRS) and peaks corresponding to vitamins $\mathrm{B}_{1}, \mathrm{~B}_{2}, \mathrm{~B}_{3}, \mathrm{~B}_{5}, \mathrm{~B}_{6}$, and $\mathrm{B}_{12}$ on the chromatogram of the work solution of the test sample (WSTS). The difference in peak time did not exceed the relative standard deviation calculated for WSRS from five consecutive chromatograms, but not more than recommended by the SPU (USPCQM, 2014-2018).

Determination of the quantitative content of vitamins $\mathrm{B}_{1}, \mathrm{~B}_{2}, \mathrm{~B}_{3}, \mathrm{~B}_{5}, \mathrm{~B}_{6}$, and $\mathrm{B}_{12}$ was carried out by high performance liquid chromatography on a liquid chromatograph LPP-205 (Czech Republic) according to the following parameters:

- chromatographic tube $250 \times 4.6 \mathrm{~mm}$;
— Luna ${ }^{\oplus}$ Omega $5 \mu \mathrm{m}$ sorbent Polar C18 $100 \AA \AA$

- mobile phase - a mixture of acetonitrile with a buffer solution;

- flow rate of the mobile phase $-1.0 \mathrm{ml} / \mathrm{min}$;

- detection at wavelengths of $195 / 265 \mathrm{~nm}$ (vitamins

$\mathrm{B}_{3}, \mathrm{~B}_{5}$, and $\mathrm{B}_{12}-195 \mathrm{~nm} ; \mathrm{B}_{1}, \mathrm{~B}_{2}, \mathrm{~B}_{6}-265 \mathrm{~nm}$ );

- tube temperature $+25^{\circ} \mathrm{C}$;

- registration scale -0.5 absorbance units;

— signal integration - computer integration;

- volume of injection - $0.010 \mathrm{ml}$.

The content of each of the vitamins in the preparation 'Energolit' is calculated by the ratio of the areas of the corresponding peaks on the chromatograms of the test sample and standard samples.

For the investigated samples quality indicators had to meet specifications and standards specified in Table 1.

Table 1 - Quality control indicators

\begin{tabular}{|l|c|}
\hline \multicolumn{1}{|c|}{ Name of the indicator } & $\begin{array}{c}\text { Specifications } \\
\text { and standards }\end{array}$ \\
\hline Description & Orange solution \\
\hline Packing volume & $250 \mathrm{ml} \pm 10.0 \%$ \\
\hline $\mathrm{pH}$ & $5.0-7.0$ \\
\hline $\begin{array}{l}\text { Identity of vitamins } \\
\mathrm{B}_{1}, \mathrm{~B}_{2}, \mathrm{~B}_{3}, \mathrm{~B}_{5}, \mathrm{~B}_{6}, \mathrm{~B}_{12}\end{array}$ & Positive \\
\hline Quantity of vitamin $\mathrm{B}_{1}$ & $0.1 \mathrm{mg} / \mathrm{ml} \pm 10.0 \%$ \\
\hline Quantity of vitamin $\mathrm{B}_{2}$ & $0.02 \mathrm{mg} / \mathrm{ml} \pm 10.0 \%$ \\
\hline Quantity of vitamin $\mathrm{B}_{3}$ & $1.5 \mathrm{mg} / \mathrm{ml} \pm 10.0 \%$ \\
\hline Quantity of vitamin $\mathrm{B}_{5}$ & $0.05 \mathrm{mg} / \mathrm{ml} \pm 10.0 \%$ \\
\hline Quantity of vitamin $\mathrm{B}_{6}$ & $0.15 \mathrm{mg} / \mathrm{ml} \pm 10.0 \%$ \\
\hline Quantity of vitamin $\mathrm{B}_{12}$ & $0.03 \mathrm{mg} / \mathrm{ml} \pm 10.0 \%$ \\
\hline Sterility & Must be sterile \\
\hline
\end{tabular}

Statistical processing of the obtained results was carried out in accordance with the SPU $(n=3)$ (USPCQM, 2014-2018; Belikov, 1985; Rokitskiy, 1973).

Results and discussion. Table 2 presents the results of experimental studies of stability, covering the physicochemical and pharmacological performance of three experimental and industrial series of vitamin and mineral preparation 'Energolit'. It was confirmed that during the two years of storage, as well as one day after the piercing of the stopper with a sterile injection needle, in the primary packaging at a temperature of from +5 to $+25^{\circ} \mathrm{C}$ and relative humidity $(60 \pm 5 \%)$, the three studied series of the preparation 'Energolit' showed stability of composition.

During the tests on changes of $\mathrm{pH}$, identity and content of the vitamins $B_{1}, B_{2}, B_{3}, B_{5}, B_{6}$, and $B_{12}$ of the experimental samples of the preparation were within possible variation. Microbial contamination (Escherichia coli, Staphylococcus aureus, Pseudomonas aeruginosa) was not detected. Fungi contamination was not detected during the study as well. In one day after the puncture contamination was less than $10 \mathrm{CFU} / \mathrm{ml}$. 
Table 2 - Experimental results of the preparation 'Energolit' stability, when stored in glass vials $(\mathrm{M} \pm \mathrm{m}, \mathrm{n}=3)$

\begin{tabular}{|c|c|c|c|c|c|c|c|c|c|c|c|c|c|c|c|}
\hline \multirow[b]{3}{*}{$\begin{array}{l}\text { Control } \\
\text { period, } \\
\text { months }\end{array}$} & \multicolumn{15}{|c|}{ Drug quality indicators } \\
\hline & \multirow[b]{2}{*}{$\begin{array}{l}\text { Des- } \\
\text { crip- } \\
\text { tion }\end{array}$} & \multirow[b]{2}{*}{ pH } & \multirow[b]{2}{*}{$\begin{array}{c}\text { Microbial } \\
\text { contami- } \\
\text { nation, } \\
\text { CFU } / \mathrm{ml}\end{array}$} & \multicolumn{2}{|c|}{ Vitamin $_{B_{1}}$} & \multicolumn{2}{|c|}{ Vitamin $B_{2}$} & \multicolumn{2}{|c|}{ Vitamin $_{3}$} & \multicolumn{2}{|c|}{ Vitamin $B_{5}$} & \multicolumn{2}{|c|}{ Vitamin B $_{6}$} & \multicolumn{2}{|c|}{ Vitamin $_{12}$} \\
\hline & & & & 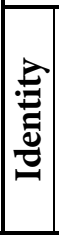 & $\begin{array}{l}\text { Quanti- } \\
\text { tative } \\
\text { determi- } \\
\text { nation, } \\
\mathrm{mg} / \mathrm{ml}\end{array}$ & 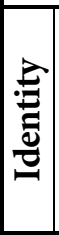 & $\begin{array}{c}\text { Quanti- } \\
\text { tative } \\
\text { determi- } \\
\text { nation, } \\
\mathrm{mg} / \mathrm{ml}\end{array}$ & 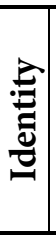 & $\begin{array}{l}\text { Quanti- } \\
\text { tative } \\
\text { determi- } \\
\text { nation, } \\
\mathrm{mg} / \mathrm{ml}\end{array}$ & 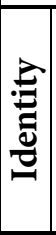 & $\begin{array}{c}\text { Quanti- } \\
\text { tative } \\
\text { determi- } \\
\text { nation, } \\
\mathrm{mg} / \mathrm{ml}\end{array}$ & 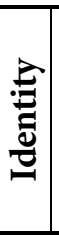 & $\begin{array}{c}\text { Quanti- } \\
\text { tative } \\
\text { determi- } \\
\text { nation, } \\
\mathrm{mg} / \mathrm{ml}\end{array}$ & 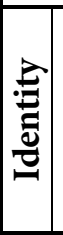 & $\begin{array}{c}\text { Quanti- } \\
\text { tative } \\
\text { determi- } \\
\text { nation, } \\
\mathrm{mg} / \mathrm{ml}\end{array}$ \\
\hline 0 & $\mathrm{C}$ & \begin{tabular}{|l|}
$5.5 \pm$ \\
0.04
\end{tabular} & $\mathrm{C}$ & $\mathrm{P}$ & $\begin{array}{c}0.103 \pm \\
0.001\end{array}$ & $\mathrm{P}$ & $\begin{array}{l}0.023 \pm \\
0.0004\end{array}$ & $\mathrm{P}$ & $\begin{array}{l}1.53 \pm \\
0.004\end{array}$ & $\mathrm{P}$ & $\begin{array}{l}0.05 \pm \\
0.007\end{array}$ & $\mathrm{P}$ & $\begin{array}{c}0.15 \pm \\
0.0004\end{array}$ & $\mathrm{P}$ & $\begin{array}{c}0.03 \pm \\
0.0004\end{array}$ \\
\hline 3 & $\mathrm{C}$ & \begin{tabular}{|l|}
$5.5 \pm$ \\
0.04
\end{tabular} & $\mathrm{C}$ & $\mathrm{P}$ & $\begin{array}{l}0.102 \pm \\
0.0008\end{array}$ & $\mathrm{P}$ & $\begin{array}{l}0.022 \pm \\
0.0004\end{array}$ & $\mathrm{P}$ & $\begin{array}{l}1.52 \pm \\
0.004\end{array}$ & $\mathrm{P}$ & $\begin{array}{l}0.05 \pm \\
0.0004\end{array}$ & $\mathrm{P}$ & $\begin{array}{c}0.15 \pm \\
0.0004\end{array}$ & $\mathrm{P}$ & $\begin{array}{c}0.03 \pm \\
0.0004\end{array}$ \\
\hline 6 & $\mathrm{C}$ & \begin{tabular}{|l|}
$5.6 \pm$ \\
0.04
\end{tabular} & $\mathrm{C}$ & $\mathrm{P}$ & $\begin{array}{l}0.102 \pm \\
0.0007\end{array}$ & $\mathrm{P}$ & \begin{tabular}{|c|}
$0.022 \pm$ \\
$0.0004^{\star}$
\end{tabular} & $\mathrm{P}$ & $\begin{array}{l}1.51 \pm \\
0.007\end{array}$ & $\mathrm{P}$ & $\begin{array}{c}0.05 \pm \\
0.0004\end{array}$ & $\mathrm{P}$ & $\begin{array}{c}0.15 \pm \\
0.0004^{\star \star}\end{array}$ & $\mathrm{P}$ & $\begin{array}{c}0.03 \pm \\
0.0004\end{array}$ \\
\hline 9 & $\mathrm{C}$ & \begin{tabular}{|l|}
$5.6 \pm$ \\
0.04
\end{tabular} & $\mathrm{C}$ & $\mathrm{P}$ & $\begin{array}{l}0.101 \pm \\
0.0004\end{array}$ & $\mathrm{P}$ & \begin{tabular}{|c|}
$0.021 \pm$ \\
$0.0004^{\star}$
\end{tabular} & $\mathrm{P}$ & $\begin{array}{c}1.50 \pm \\
0.004^{*}\end{array}$ & $\mathrm{P}$ & $\begin{array}{c}0.05 \pm \\
0.0007^{*}\end{array}$ & $\mathrm{P}$ & $\begin{array}{c}0.15 \pm \\
0.0004^{\star \star}\end{array}$ & $\mathrm{P}$ & $\begin{array}{c}0.03 \pm \\
0.0008\end{array}$ \\
\hline 12 & $\mathrm{C}$ & \begin{tabular}{|l|}
$5.6 \pm$ \\
0.04
\end{tabular} & $\mathrm{C}$ & $\mathrm{P}$ & $\begin{array}{l}0.101 \pm \\
0.0004\end{array}$ & $\mathrm{P}$ & \begin{tabular}{|c|}
$0.021 \pm$ \\
$0.0004^{\star \star}$
\end{tabular} & $\mathrm{P}$ & $\begin{array}{c}1.49 \pm \\
0.004^{\star \star}\end{array}$ & $\mathrm{P}$ & $\begin{array}{c}0.05 \pm \\
0.0007^{*}\end{array}$ & $\mathrm{P}$ & $\begin{array}{c}0.15 \pm \\
0.0012^{\star}\end{array}$ & $\mathrm{P}$ & $\begin{array}{c}0.03 \pm \\
0.0008\end{array}$ \\
\hline 18 & $\mathrm{C}$ & \begin{tabular}{|l|}
$5.5 \pm$ \\
0.04
\end{tabular} & $\mathrm{C}$ & $\mathrm{P}$ & $\begin{array}{l}0.100 \pm \\
0.0004\end{array}$ & $\mathrm{P}$ & \begin{tabular}{|c|}
$0.019 \pm$ \\
$0.0004^{\star \star}$
\end{tabular} & $\mathrm{P}$ & $\begin{array}{c}1.48 \pm \\
0.007^{\star *}\end{array}$ & $\mathrm{P}$ & $\begin{array}{c}0.05 \pm \\
0.0004^{\star *}\end{array}$ & $\mathrm{P}$ & $\begin{array}{c}0.15 \pm \\
0.0012\end{array}$ & $\mathrm{P}$ & $\begin{array}{c}0.03 \pm \\
0.0004^{\star}\end{array}$ \\
\hline 24 & $\mathrm{C}$ & \begin{tabular}{|l|}
$5.6 \pm$ \\
0.04
\end{tabular} & $\mathrm{C}$ & $\mathrm{P}$ & $\begin{array}{l}0.099 \pm \\
0.0007^{\star}\end{array}$ & $\mathrm{P}$ & \begin{tabular}{|c|}
$0.019 \pm$ \\
$0.0004^{\star \star}$
\end{tabular} & $\mathrm{P}$ & $\begin{array}{c}1.48 \pm \\
0.011^{\star}\end{array}$ & $\mathrm{P}$ & $\begin{array}{c}0.05 \pm \\
0.0008^{*}\end{array}$ & $\mathrm{P}$ & $\begin{array}{c}0.15 \pm \\
0.0015\end{array}$ & $\mathrm{P}$ & $\begin{array}{c}0.03 \pm \\
0.0007^{\star}\end{array}$ \\
\hline $\begin{array}{c}1 \text { day after } \\
\text { piercing }\end{array}$ & $\mathrm{C}$ & \begin{tabular}{|l|}
$5.7 \pm$ \\
$0.04^{*}$
\end{tabular} & $\mathrm{C}$ & $\mathrm{P}$ & $\begin{array}{l}0.099 \pm \\
0.0011\end{array}$ & $\mathrm{P}$ & \begin{tabular}{|c|}
$0.018 \pm$ \\
$0.0008^{\star \star}$
\end{tabular} & $\mathrm{P}$ & $\begin{array}{c}1.48 \pm \\
0.015^{*}\end{array}$ & $\mathrm{P}$ & $\begin{array}{c}0.05 \pm \\
0.0011^{* *}\end{array}$ & $\mathrm{P}$ & $\begin{array}{c}0.15 \pm \\
0.0025\end{array}$ & $\mathrm{P}$ & $\begin{array}{c}0.03 \pm \\
0.0011^{\star}\end{array}$ \\
\hline
\end{tabular}

Notes: $^{*}-\mathrm{p}<0.05$; $^{* *}-\mathrm{p}<0.01$ in comparison before control; $\mathrm{C}-$ corresponds; $\mathrm{P}-$ positive.

It should be noted that the preparation meets SPU indicator for microbiological purity. The spectrophotometric studies of the samples compared with the initial data confirm the results that the spectra of the studied samples are not significantly different.

Thus, the results of the results of stability studies indicate the rationality of the composition and manufacturing technology of the preparation. The components are selected according to the technological purpose, physical, chemical and functional characteristics.

Conclusions and prospects for further research. The optimal terms of storage of the preparation when stored in vials of light glass in consumer packaging - at a temperature of up to $25^{\circ} \mathrm{C}$ and a relative humidity of $60 \pm 5 \%$ that meets our climatic conditions has been determined. The obtained experimental data indicated that the shelf life of the preparation 'Energolit' is 2 years. The $\mathrm{pH}$ and mass fraction of the vitamins $\mathrm{B}$ group were unchanged or within the possible variation in the tested samples during the study, and microbial contamination was not detected. The research results are included in the new preparation registration dossier.

Further research will be focused on determination the experimental samples of the injectable preparation 'Energolit' specific activity in the conditions of an extended shelf-life.

\section{References}

Belikov, V.G. (1985) Pharmaceutical chemistry [Farmatsevticheskaya khimiya]. Moscow: Vysshaya shkola [in Russian].

Kotsiumbas, I. Ya., Malyk, O. H., Patereha, I. P., Tishyn, O. L. and Kosenko, Yu. M. (2006) Preclinical studies of veterinary drugs [Doklinichni doslidzhennia veterynarnykh likarskykh zasobiv]. Lviv: Triada plus. ISBN 9667596648. [in Ukrainian].

Rokitskiy, P. F. (1973) Biological statistics [Biologicheskaya statistika]. $3^{\text {rd }}$ ed. Minsk: Vysheyshaya shkola. [in Russian].

Sachuk, R. M. (2018) 'Investigation of acute toxicity and local irritation of the vitamin-mineral preparation «Energolit»" [Vyznachennia parametriv hostroi toksychnosti ta mistsevo- podrazniuiuchoi dii vitaminno-mineralnoho preparatu «Enerholit»], Veterinary Biotechnology [Veterynarna biotekhnolohiia], 33, pp. 109-116. Available at: http://nbuv.gov. ua/UJRN/vbtb_2018_33_16. [in Ukrainian].

Tykhonov, O. I. and Yarnykh T. H. (2016) Pharmacy drug technology [Aptechna tekhnolohiia likiv]. $4^{\text {th }}$ ed. Vinnytsia: Nova knyha. ISBN 9789663825571. [in Ukrainian].

USPCQM [Ukrainian Scientific Pharmacopoeial Center for Quality of Medicines] (2014-2018) State Pharmacopoeia of Ukraine [Derzhavna Farmakopeia Ukrainy]. $2^{\text {nd }}$ ed. Kharkiv: USPCQM [in Ukrainian]. 